\title{
Sunda Wiwitan: The Belief System of Baduy Indigenous Community, Banten, Indonesia
}

\author{
Enjang AS ${ }^{1}$, Mukhlis Aliyudin ${ }^{2}$, Muhibudin Wijaya Laksana, ${ }^{3, *}$, Farid Soleh Nurdin ${ }^{4}$, Sitta \\ Resmiyanti Muslimah', Widodo Dwi Ismail Azis ${ }^{6}$ \\ UIN Sunan Gunung Djati Bandung, Indonesia; enjang_as@uinsgd.ac.id \\ UIN Sunan Gunung Djati Bandung, Indonesia; mukhlis.aliyudin@uinsgd.ac.id \\ 3 UIN Sunan Gunung Djati Bandung, Indonesia; muhibudinwijayalaksana@uinsgd.ac.id \\ 4 UIN Sunan Gunung Djati Bandung, Indonesia; farid.s.nurdin@uinsgd.ac.id \\ UIN Sunan Gunung Djati Bandung, Indonesia; sittarmuslimah@uinsgd.ac.id \\ 6 UIN Sunan Gunung Djati Bandung, Indonesia; widodo.dia@uinsgd.ac.id \\ * Correspondence: muhibudinwijayalaksana@uinsgd.ac.id
}

Received: 2020-03-27; Accepted: 2020-06-07; Published: 2020-06-29

\begin{abstract}
The purpose of this study is to determine the construction of the meaning of Sunda Wiwitan religion in Sundanese Baduy indigenous people. The research uses interpretive paradigms with qualitative methods, and symbolic interaction study approaches as a tool of analysis. Data gathered through participatory observation and in-depth interviews. Sunda Wiwitan religion is the main symbol in the Baduy indigenous people, and is a dimension that reaches every side of life, and is a collective representation of the belief system of the Baduy indigenous community. This symbol serves as a reference for the collective paradigm, and as a reference for interpreting natural phenomena and determining the behavior of the Baduy indigenous people. The symbol of traditional institutions and traditional ceremonies represent three essential issues, namely: (1) Understanding and appreciation of religion (belief) of the Baduy indigenous people as Sunda Wiwitan descendants; (2) Observance and practice of the daily life of the Baduy indigenous people as members of the traditional Sundanese or Sunda Buhun social groups; and (3) Symbolization of the existence and recognition of the existence of government and power outside the Baduy Customary institution.
\end{abstract}

Keywords: Baduy; indigenous; religion; Sunda Wiwitan; Symbolic Interaction.

\begin{abstract}
Abstrak: Tujuan penelitian ini adalah untuk mengetahui konstruksi makna Agama Sunda Wiwtitan pada masyarakat Adat Sunda Baduy. Penelitian menggunakan paradigma interpretif dengan metode kualitatif dan pendekatan studi interaksi simbolik sebagai pisau analisa. Sumber data dalam penelitian dari observasi partisipatif dan wawancara mendalam. Agama Sunda Wiwitan menjadi simbol utama pada masyarakat Adat Baduy, dan merupakan dimensi yang menjangkau secara luas setiap sisi kehidupan, serta merupakan representasi kolektif keyakinan (collective belief) masyarakat Adat Baduy. Simbol ini menjadi acuan paradigma kolektif, dan sebagai acuan menafsirkan fenomena alam dan menentukan perilaku masyarakat Adat Baduy. Simbol lembaga adat dan upacara adat sebagai simbol yang merepresentasikan tiga persoalan penting, yaitu: (1) Pemahaman dan penghayatan keagamaan (keyakinan) masyarakat Adat Baduy sebagai keturunan Sunda Wiwitan; (2) Ketaatan dan pengamalan kehidupan sehari-hari masyarakat Adat Baduy sebagai anggota kelompok sosial masyarakat Sunda tradisional atau Sunda Buhun; dan (3) Simbolisasi atas eksistensi dan pengakuan pada keberadaan pemerintahan dan kekuasaan di luar lembaga Adat Baduy.
\end{abstract}

Kata Kunci: adat; agama; Baduy; Interaksi Simbolik; Sunda Wiwitan. 


\section{Introduction}

The Baduy indigenous people are administratively settled in the area of Kanekes village, Leuwidamar, Lebak, Banten Province. They deliberately alienate themselves from the lives of outside cultures to fulfill the mandate of their ancestors (karuhun), preserving the sasaka buana heritage, preserving the balance and harmony of the universe. Obedience to the order of ancestors (karuhun) appears in the form of a social system that is enforced in their daily lives. So, the everyday life of the Baduy indigenous people is natural (basajan), and confined to the problem of fulfilling the material needs excessively. They are still holding firm to the burdens pikukuh ${ }^{1}$ inherited by their ancestors from generation to generation.

The Baduy indigenous people, with their group identities and local cultural characteristics that are so unique and distinctive, make it seen as a manifestation of the traditional Sundanese community, a model of "origin" Sundanese society, Buhun, and also referred to as Jatisunda (Sundanese origin). Various cultural characteristics found in the Baduy indigenous people are ultimately seen as cultural identity with the authenticity of the traditional Sundanese culture through the Sunda Wiwitan belief system.

The Sunda Wiwitan belief is considered as a native religion of the Sundanese people, the first-religion, origin, principal, or Jatisunda. Their strong commitment to the teachings of Sunda Wiwitan religion, customs, value systems, and spatial systems is based on their cosmology that passed down from generation to generation. These traditions are unique and probably influenced by the message of the pikukuh Baduy, which is part of the teachings of Sunda Wiwitan mentioned in the buyut karuhunan (ancestral ban).

So strong are the teachings of the Sunda Wiwitan belief in the life activities of the Baduy indigenous people, that they can take care of and defend the value system. How they cultural system and customs survive in the massive modernization current is deemed essential to conduct a study to explore and construct about how the Sunda Wiwitan belief system that influenced the daily life of the Baduy indigenous community.

This study reinforces previous studies of the religious characteristics of Sundanese people about the cosmological beliefs of the natural surroundings. Wessing's study at Pameuntasan Bandung, states that Sundanese people cannot be separated from nature space, which is believed to be inhabited by various creatures, both natural and supernatural, which are integrated into a single unit (Wessing, 1975). Similarly, Qodim stated in his study in Kuta Ciamis village, that the Sundanese religious structure that is magical and ritualistic could not be separated from the surrounding natural conditions. Kuta people who live around the forest believe that the prohibited forest and around their homes are surrounded by cosmic forces of the Sacred (Qodim, 2019). Besides, Abdul Syukur's study in Dukuh, Garut, also stated that in addition to the Islamic tradition, the Dukuh community has a belief system of ancestral myths, occult sanctions, and particular rituals in preserving nature and the environment (Syukur \& Qodim, 2016).

In the case of the Sunda Wiwitan religion adopted by the Baduy community, some previous studies also stated that the belief was related to the cosmology of the surrounding nature and the mandate of the ancestors (pikukuh karuhun). Hakim's research, for example, states that the cultural and spiritual values of the Baduy are related to beliefs and myths centered on the prohibited forest, where their site is located, Sasaka Domas (Hakim, 2006). Masykur Wahid also concluded that the Baduy's belief in Sunda Wiwitan teachings was a spirit of maintaining the balance of forests, rivers, and mountains living in harmony, by performing ritual ceremonies in Sasaka Domas as a Baduy holy land (Wahid, 2012). Similarly, Retti Isnendes stated that the Seba Ceremony was the implementation of pikuhuh karuhun, which was institutionalized in the Sunda Wiwitan religion and functioned as an activity of advising each other in maintaining cosmic balance and the harmony of the universe for the welfare of humanity (Isnendes, 2016).

\footnotetext{
${ }^{1}$ Pikukuh is the ancestral (karuhun/ancestors) mandate which is passed down through the centuries to the customs of the Kanekes community including: values, norms and laws and traditions implemented in the form of prohibitions.
} 
Previous studies on the strength of Pikukuh Karuhun in Baduy society as a strategy to survive the current changes in modernization were carried out by Siti Nadroh and Kiki. Nadroh, in his study, stated that pikukuh karuhun is still strongly embraced by the Baduy community and continues to survive until now amidst the current changes in modernization. Pikukuh karuhun Baduy is believed to be a representation of Baduy's identity to show the personality of 'Urang Baduy' by respecting karuhun, take care of, and preserves the environment and living together in cooperation, deliberating for consensus (Nadroh, 2018). Kiki, in his study, also concluded that the polite and honest behavior possessed by the Baduy indigenous people was caused by their strong belief in the buyut karuhun. The most crucial concept in pikukuh karuhun is the concept of provisions 'without any changes' or as few changes as possible that make them careful and obedient in carrying out the various pikukuh adat in their daily lives (Hakiki, 2015).

Based on several previous studies above, it can be seen that the importance of Sunda Wiwitan's beliefs for the Baduy indigenous people is that the meaning of their faith is shown through the symbols they use in their daily lives. Unlike the previous studies, this study looks at the Sunda Wiwitan religion from the perspective of the symbolic interaction approach.

The meaning of the Baduy indigenous people towards the religiosity of their beliefs, of course, is the result of such a long communication, because the meaning itself is the result of interaction with others. Littlejohn and Foss explained that: "Meaning is an important outcome of communication. Your meanings are the result of interaction with others" (Littlejohn, S. W. \& Foss, 2012). Thus, the meaning of lives in the Baduy community also a result of their interpretive process of reality. This process becomes a 'social product,' and the Baduy indigenous people produce "creation that is formed through defining human activities when they interact." Cultural values that have been inherited across the generation are maintained during interactions and communication through familiar symbols.

Baduy indigenous people use various symbols in their interactions, either among themselves or among outside communities. These symbols are seen as a representation of the way of thinking and attitude of those who are committed to the continuity of the value system, customs, and other cultural norms that are hereditary from generation to generation.

Based on the description mentioned above, it is interesting to research the Sunda Wiwitan religion in the Baduy indigenous people. This research employs a qualitative method with a symbolic interaction study approach. The objective condition of the Baduy indigenous people as traditional "Sunda Buhun," a traditional community, it is considered appropriate by using qualitative research. Also, other reasons are based on the consideration that the character of a qualitative study seeks to uncover and understand phenomena about what is experienced by research subjects holistically and in a transparent manner in the form of words and language in a particular context naturally (Moleong, 2011).

\section{Symbol and Cultural Representation}

Symbols have and still have a significant meaning in human life, because symbols are the basis of individual identity and social life, as Mead explained as quoted by Wood (1997) that "Mead thought that symbols were the basis of individual identity and social life." Once the meaning of a symbol for humans is complex human society demands and relies on the symbol of life. Human dependence on symbols is because symbols represent something beneficial for communication (Syam, 2009).

Through symbols, humans can represent the reality they want to convey, and through symbols, all cultural meanings are created. The human also interacts and communicates through symbols. Because of the importance of symbols in human life, all cultural implications are created by using symbols (Spradley, 2007). Clifford Geertz's also emphasized that meaning can only be stored within symbols (Clifford, 1973). Susanne K. Langer further noticed that "one of the basic human needs is the need for symbolization or use of symbols" (Mulyana, 2010).

Susanne K. Langer holds that symbolism underlies all knowledge and understanding of all humans. Even Langer, in her theory, emphasized some concepts and terms commonly used in the field of communication, as well as providing a kind of standardization for the semiotic tradition in communication studies. The symbol theory developed by Susanne Langer is based on the assumption that all living animals are dominated by feelings, but human emotions are mediated by conceptions, 
symbols, and language. Therefore, humans do not just respond to simple signs, because more than that, humans use symbols (Littlejohn, S. W. \& Foss, 2012).

Symbols are forms that mark something else outside the embodiment of the symbolic form itself (Sobur, 2017). Langer explained signs as a stimulus that signifies the presence of something. A sign is closely related to the meaning of the actual event. Symbols are used in more complex ways by getting someone to think about something separate from his presence. Langer explained further that a symbol is an instrument of thought, a symbol is a human conceptualization of something, and a symbol exists for something. Susanne Langer stated that: "A symbol is an instrument of thought. Symbols are human conceptualizations about things: a symbol stand for something else" (Littlejohn, S. W. \& Foss, 2012). Meanwhile, according to Marcel Danesi, the so-called "symbol is a sign that represents the object through agreement or agreement in a specific context" (Danesi, 2010).

In the context of this study, symbols in the Baduy indigenous people are not something separate from the local socio-cultural side, because the culture is a system through which humans communicate, preserve, and develop knowledge about life and attitudes towards life. Even the symbols that live in the Baduy indigenous people are used to represent the reality they want to convey (symbols do more than represent things. They do more than communicate meaning).

On the other hand, the symbols that live in Adat Baduy refer to cultural concepts that develop amid society, because symbols do not appear in a vacuum and independent of socio-culture, but live and grow in a cultural context or specific situation. Thus, the existence and use of symbols in a particular community are not as simple as in the use of signs that are closely related to the actual events (signification). Because the symbol is an instrument of thought, it is even a human conceptualization of something to convey.

This study utilizes a symbolic interactionism approach to analyze the ways the Baduy indigenous people interpret Sunda Wiwitan symbols in their interactions and communication with others. This theory affirms that individuals form meaning through communication processes because meaning is not intrinsic to anything, so creating the same purpose requires interpretive construction among the people who interact. West and Turner explain that: "Symbolic Interaction theory holds that individuals construct meaning through the communication process because meaning is not intrinsic to anything. It takes people to make meaning" (West \& Turner, 2018).

The theory of symbolic interactionism is based on ideas about self and its relationship with society, and social life is human interaction using symbols. Theorists of symbolic interactionism, in this case, are interested in the way humans use symbols that represent what they mean to communicate with each other (Mulyana, 2010).

Based on the explanation above, this study aims to explain what kind of symbols of Sunda Wiwitan beliefs are used by the Baduy indigenous people? How do they interpret these symbols? And how do they use these symbols?

The data in this study were sourced from participatory observation and in-depth interviews. The interview is conducted with several important informants in the Baduy community. They are (1) Puun, the highest leaders who manage all the spiritual matters, safeguard the nature, the environment, and the lives of all humanity (Ngabaratapakeun, ngabaratanghikeun, and ngasuh ratu nyanyak menak). Puun also the supreme giver of customary law in the context of carrying out the wiwitan mandate who know all information related to Baduy from the origin, characteristics, beliefs (religion), geographical location, population, everyday language, livelihood, education, health, institutions, leadership systems, customs and ceremonies (rituals) like religious rituals, birth and death, marriage, and other rituals. (2) Jaro Tangtu, who carry out the governmental wheel and all customary laws. Jaro Tangtu is a person who is considered to know and understand the principles of implementing customary laws. Jaro Tangtu means the predecessor community or the forerunner, or in the view of the Baduy indigenous people means certain (definite). (3) Deputy Jaro Tangtu as a representative of Jaro Tangtu and referred to as Jaro Parawiri, is part of the elements of the Baduy indigenous community leaders who assist Jaro Tangtu. Deputy Jaro Tangtu served for the implementation of traditional ceremonies, especially in preparing tools and needs for deliberations and traditional services, like the ceremony of kawalu, ngalaksa, and 
Seba and other religious ceremonies. During the fieldwork, it was Deputy Jaro Tangtu in Cibeo, who actively gave information because he serves as a spokesman or information providers for the Baduy indigenous people, both to the local and external communities of the Baduy indigenous people. (4) Jaro Pamarentah, who can be considered as the village head and in charge of the Baduy indigenous community relations with the government. Jaro Pamarentah, is also considered to know and understand the traditional principles of the Baduy indigenous people.

Baduy consists of three villages: Cibeo or also called tangtu Parahiyang, Cikartawana or also called Tangtu Kadu Kujang, and Cikeusik or also called Tangtu Pada Ageung. The third tangtu is also known as Telu Tangtu, Baduy Jero, Urang Kajeroan, or Baduy Dalam.

Based on the nature of qualitative research, information is not only related to human activities but also in the form of events, conditions, and situations observed in research. Sources of information in this study were obtained objectively (purposive). The required data is obtained from key informants stated above as preliminary data.

\section{Sunda Wiwitan: The Belief system of Baduy Indigenous Community}

Baduy indigenous people adopted Sunda Wiwitan as their religion that specificly belong to them and not widely adhered by people outside the community. Concerning the faith of Sunda Wiwitan, Ayah Mursid (Personal Communication, May 17, 2012), Deputy Jaro Tangtu Cibeo explains:

Agama sunda wiwitan nu diagem ku masyarakat Baduy ngarana Agama Slam Sunda Wiwitan, nabina

Nabi Adam Tunggal. Dina kayakinan Sunda Wiwitan kami mah teu kabagean parentah shalat saperti dulur-dulur, sabab wiwitan Adam tugasna miara kasaimbangan ieu alam, jeung teu ngabogaan kitab jiga agama Islam, da ajaranana nerap jeung alam, makana agama Slam Sunda Wiwitan ngan ukur keur urang Baduy.

(The Sunda Wiwitan religion that is embraced by the Baduy people is called Sunda Wiwitan Slam, which we received from the prophet Adam Tunggal. In Sunda Wiwitan's belief, there are no prayer orders like in Muslim because Wiwitan Adam is in charge of maintaining the balance of nature. We also do not have a holy book like Islam because Adam's teachings mingle with the environment; therefore, the Sunda Wiwitan Slam religion is adhered explicitly by and for the Baduy community).

Based on the above statement, it can be ascertained that in Sunda Wiwitan no scripture can be used as a written guide to religious practice. The teaching of Sunda Wiwitan is unified with the universe and served to maintain the balance of nature.

Thus, there is not much information that can be explored in terms of the teachings of Sunda Wiwitan, because the Kanekes enclosed related the knowledge of belief (religion). The indigenous peoples may view that the Sunda Wiwitan is only for Indigenous peoples; it is also very likely that they are influenced by the long history and the complexities of their experiences. Thus, the inclusion of these questions is one of the strategies for their survival, security, and comfort in exercising their (religious) beliefs. Their belief also differs significantly in the content to that of the Arab community. The indigenous people's indifference to the content of their religious teachings is seen as part of caution, and part of the strategy to preserve the teachings they believe.

The religion of Sunda Wiwitan contains the highest power rests in Sang Hiyang Keresa (the Almighty) or Nu Ngersakeun (the Desirable), called Batara Tunggal (The One Almighty God), Batara Jagat (the Ruler of Universe), and Batara Séda Niskala (Saringendyanti \& Mahzuni, 2018) housed in Buana Nyungcung (Rosidi, 1984). In the understanding of the Kanekes, all the deities in the concept of Hinduism (Brahma, Wisynu, Syiwa, Indra, Yama, etc.) were subject to Batara Séda Niskala.

Furthermore, in the cosmological view in Sunda Wiwitan religious teachings, there are three kinds of nature according to the mythology of the Baduy indigenous people, as expressed in the pantun story. The three types of nature in question are (1) Buana Nyuncung, where Sang Hiyang Keresa resides, which is at the top, (2) Buana Panca Tengah, home to humans and other creatures; (3) Buana Lanang, is the lowest place, which is hell. Between Buana Nyuncung and Buana Panca Tengah there are 18 natural layers arranged from top to bottom. The uppermost layer is called Bumi Suci Alam Padang, which is also known 
as Alam Kahiyangan or Mandala Hyang, and this layer is the residence of Nyi Pohaci Sanghyang Asri and Sunan Ambu.

Nyi Pohaci is a term for the figure of Dewi Sri; she is a rice protector in the Sundanese belief, she is a respected figure where the honor is manifested in various rice harvesting ceremonies (Holil, 2020). Sunan Ambu is a divine mother who is in Alam Kahiyangan (Kahiyangan Nature), where Sang Hyang Tunggal is located (Isfiaty \& Santosa, 2020). Sunan Ambu may be the embodiment of Dewi Sri (Sumarjo, 2003).

In the belief of the Baduy indigenous people, the world (Buana Panca Tengah) are distinguished by their level of purity. Sasaka Pusaka Buana is considered the most sacred place, almost side by side with Sasaka Domas. Furthermore, sequentially with the decreasing level of innocence is the Inner village (tangtu region), the outer village (panamping) ${ }^{2}$, Banten, Sunda Land, and outside Sunda. Sasaka Pusaka Buana became the center of the world and also the center of the village environment in the (Tangtu region). Baduy Dalam is the center of the Banten area, and Banten is the center of the Sunda Land environment.

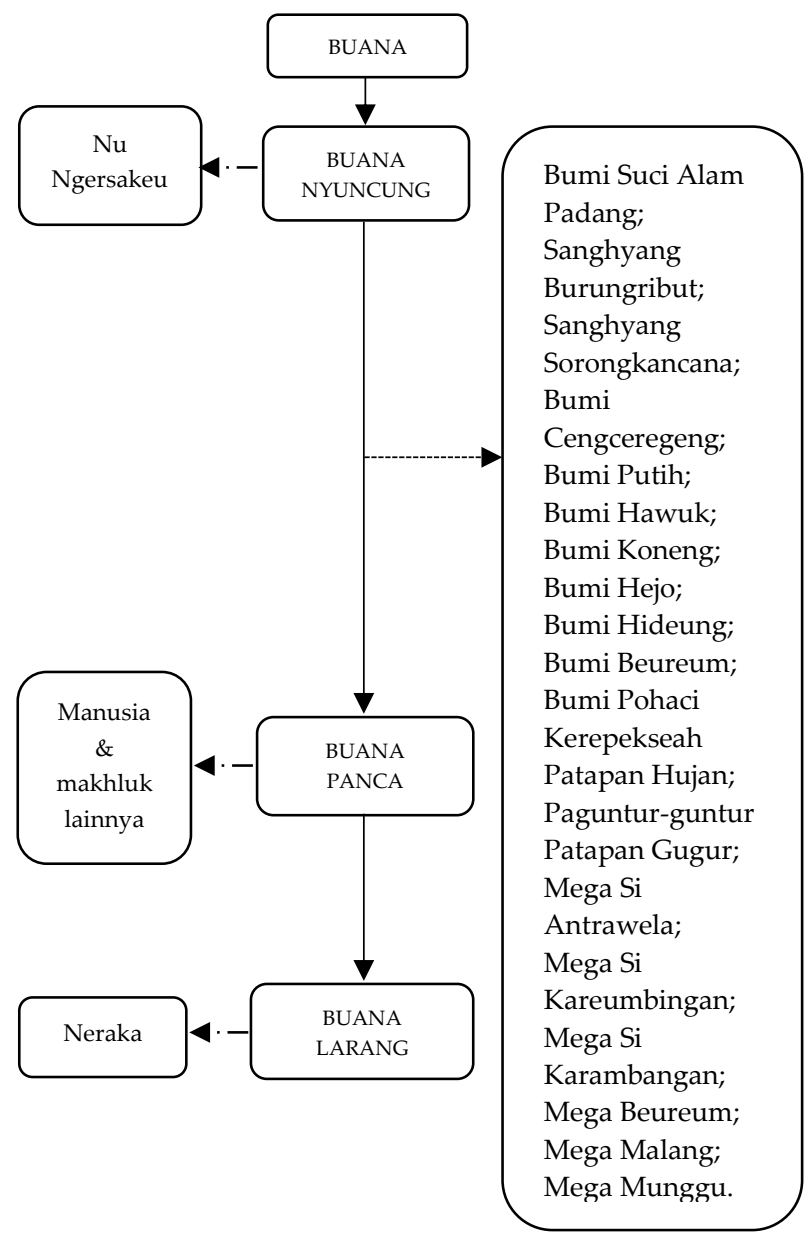

Figure 1 the structure of the universe in the Baduy Cosmology

\footnotetext{
${ }^{2}$ The Panamping community group is the community known as the Baduy Indigenous people outside. The word panamping itself comes from the word tamping which means throwing away. Another opinion says that panamping means the edge or edge area. Panamping is a place for parents who come out of Tangtu because it violates customs.
} 


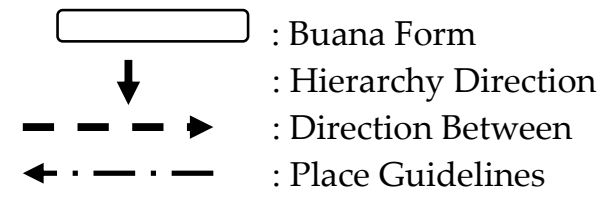

Figure 1 explains that the cosmological view of the Baduy community regarding the existence of the universe, basically the cosmological nature is divided into three regions, namely: (1) Buana Nyungcung which is Nu Ngersakeun burial place; (2) Buana Panca Tengah which is a place where humans and other creatures live; and (3) Buana Larang (hell). Between Buana Nyungcung and Buana Panca Tengah there are 18 layers of nature or the world in which the order is arranged from top to bottom, and the arrangement is as follows: Buana Nyungcung; Bumi Suci Alam Padang; Sanghyang Burungribut; Sanghyang Sorongkancana; Bumi Cengceregeng; Bumi Putih; Bumi Hawuk; Bumi Koneng; Bumi Hejo; Bumi Hideung; Bumi Beureum; Bumi Pohaci Kerepekseah Patapan Hujan; Paguntur-Guntur Patapan Gugur; Mega Si Antrawela; Mega Si Kareumbingan; Mega Si Karambangan; Mega Beureum; Mega Malang; Mega Munggu; dan Buana Panca Tengah. Specifically, about Bumi Suci Alam Padang, this second layer of nature is also called "Mandala Kahyangan" or "Kahyangan," and this is where Nyi Pohaci Sanghyang Asri and Sunan Ambu are. The second nature is very close to Buana Nyungcung because the distance is only "sagorolong jeruk mipis" (a roll of lime).

The belief system of Indigenous peoples contains many kinds of taboo (buyut) that need to be avoided. People of Baduy even reluctant to say (teu wasa) to avoid transgressing them. Two types of prohibition indicated, namely (1) buyut adam tunggal that applies to Baduy in Kanekes (Baduy dalam); and (2) buyut nahun that occurs for the panamping and dangka (villagers outside Kanekes) (Ekadjati, 2014).

Buyut Adam Tunggal is a taboo that covers the essential matter and its derivations. Whereas, buyut nahun direct only to the common taboo. Therefore, some restrictions in the panamping area, which are considered standard in daily life, in tangtu community (Baduy Dalam), it is restricted (tabu). Besides, taboo classified into three categories based on its goals in Baduy indigenous peoples, are (1) taboo to protect human souls; (2) taboo to guard the purity of the mandala; and (3) taboo to preserve the tradition.

The first taboo is based on the belief of Baduy ancestors that the soul or human spirit originates from Kahiyangan and that when life in the Buana Panca Tengah is completed, the soul must return to Kahiyangan. The soul, when it comes down from Kahiyangan Sukma was in a good (rahayu) condition; thus, it should return in good condition too. If the soul gets dirty, then hell is a place to return. The goodness of the soul when it returns depends on the good deed the human do in the Buana Panca Tengah.

In performing the task, the soul is provided with a body consisting of 10 different senses. The use of the senses for good deeds will make the soul well-nourished. On the contrary, the use of the senses for evil deeds will pollute the soul. Thus, it is best to rely on the daily life of the human being in the use of 10 different forms. To ensure that the senses are utilized for good works, there are restrictions and instructions on using them.

The second taboo is based on the notion of the Baduy territory of their ancestry as mandala or kabuyutan. Mandala is a sacred area. Within the mandala environment, there are areas or places of varying purity, as stated above. According to Indigenous peoples, the position of their place of residence as a mandala continues to this day and will continue until the end of the world (rupak alam dunya). The existence of this taboo is to keep the area of the mandala holy. Then the amount of restriction and the difficulty level depends on the level of purity of the place. For example, in Sasaka Pusaka Buana, the number of taboo and difficulty levels differ from that of in other areas such as in tangtu area and panamping area.

The religious life of Baduy indigenous people is reflected in religious ceremonies and several restrictions (taboo), as well as instructions (mandates) derived from their ancestors. Religious ceremonies are among them; ngukus, muja, ngawalu, and ngalaksa, as illustrated in the duties of the indigenous people, are: 
1) Ngaréksakeun Sasaka Pusaka Buana (preserve the place of worship at the Sasaka Pusaka Buana);

2) Ngaréksakeun Sasaka Domas (preserve the place of worship in Sasaka Domas);

3) Ngasuh ratu ngajayak ménak (nourishing the ruler and hugging the nobles);

4) Ngabaratapakeun nusa telu puluh telu, bagawan sawidak lima, pancer salawé nagara (defending 33 homeland, 65 river, and 25 states);

5) Kalanjakan kapundayan (hunting and fishing for kawalu ceremonial purposes); and

6) Ngukus ngawalu muja ngalaksa (burning incense while worshiping, performing the Kawalu Ceremonial and Ngalaksa Ceremonial)

The patterns and way of life of Baduy indigenous peoples cannot be separated from their belief system. They live side by side with all these prescriptions and prohibitions associated with the customary and prevailing laws and pikukuh.

It is interesting to note that in Baduy indigenous society, there is no sacred place for holy objects such as mosque and statues for them to worship, nor scriptures for them to read as guidelines for their lives. In Baduy indigenous society, it is prohibited to learn how to write and read by the provisions of their ancestors.

The holy books of Baduy indigenous peoples are the universe. Therefore, their mandate is to preserve and sustain its equilibrium. Thus, any attempts to destroy the environment is similar to damaging their own beliefs. This belief rests on Yang Tunggal (The One), Sang Hyang Keresa (the Almighty), or Nu Ngersakeun (the One Who has the power), also called the Batara Tunggal (the Almighty), and Batara Jagat (Ruler of the universe), the origin of all things.

In the belief of the indefatigable Baduy indigenous people, $\mathrm{Nu}$ Ngersakeun should not be mentioned carelessly, for it cannot be compared with anything else that mortal. Consequently, it is prohibited to draw, write, and read since letters and numbers are an image. The reason for this prohibition is that any object (including image or writing) would mostly have content, essence, substance, accessibility, equality, so it was very likely to be imagined in the form of reality (empirical). Meanwhile, nu ngersakeun is incomparable to anything else in the universe. Thus, God (The One) of the Baduy peoples is not shaped and does not depend on space and time. The Baduy indigenous people believe their God exists everywhere and encompasses everything (Universum), and is not dependent on time. Based on this understanding, too, there is a statement to the Baduy indigenous Peoples community that reads; "Hiji tanpa wilangan" (one without number), This 'one is many.'

Batara Tunggal, the center of the belief of Baduy peoples, can be interpreted as the One encompasses everything (universum). So this approach goes back to the sum of all conditions that fall into Singularism. When this Batara Tunggal is considered to merge with the universe, it falls to the view that they are pantheistic, that the Batara Tunggal is considered to be immanent. However, in the eyes of the Baduy ancestors, above the Batara Tunggal, there is still a power that cannot be named and cannot be told, so it did not fall to Pantheismus, but Panentheismus. They considered God not only to fulfill and absorb nature but to transcend it. In this case, then, God in the belief system of Baduy community is limited. Limited means reside in space. This finding is in contrast with the report, according to Suria Saputra (1998), that the God of the Baduy peoples is unlimited and spaceless (Sumardjo, 2009). Baduy indigenous peoples (especially Baduy Dalam) are obedient and faithful to their belief system. Baduy belief system is different from that of most believed by the majority of people in Indonesia. However, based on the Durkheim definition of religion that belief in God or supernatural power, that consider "sacred," and make the people calm and comfort to the individual who embraces it, Baduy belief system fall as religion.

The Baduy indigenous peoples' adherence to the teachings of Sunda Wiwitan as their beliefs (religion), also known as the Jatisunda religion, is part of the implementation of the Pikukuh Baduy, which is rooted in buyut titipan karuhun (great-grandparents), as table 1.

The belief system that exists in Sunda Wiwitan influences various aspects of Baduy community life with its cosmological concept, namely Tri Tangtu, which is translated into religious, political, developmental, and other social life (Miharja, 2015). 
The concept of Tri Tangtu consists of three categories, namely Tri Tangtu dina Raga (Salira), Tri Tangtu dina Nagar, and Tri Tangtu dina Buana. Tri Tangtu dina Raga (Salira) means a system of reciprocity to human transcendence with lampah, tekad, ucap or bayu-sabda-hedap (deed, strong will, and word). Tri Tangtu dina Nagar is a unitary Rsi-Ratu-Rama (cleric, ruler, and a wise old man); meanwhile, Tri Tangtu dina Buana, is a relationship that must be established in harmony between Lord or Hiyang/Hyang, the universe, and human (Saringendyanti, Herlina, \& Zakaria, 2018).

Table 1 buyut titipan karuhun (great-grandparents)

Buyut nu dititipkeun ka puun

Nagara satelung puluh telu

bagawan sawidak lima

Pancer salawe nagara

Gunung teu meunang dilebur

lebak teu meunang dirusak

larangan teu meunang dirempak

buyut teu meunang dirobah

lojor teu meunang dipotong

Pondok teu meunang disambung

Mipit kudu amit, ngala kudu menta

Ngagedig kudu bewara

Neukteuk kudu sateukna

Nilas kudu saplasna

Ngadek kudu saclekna

$\mathrm{Nu}$ lain kudu dilainkeun

Nu enya kudu dienyakeun
(Buyut yang dititipkan kepada puun/ Greatgrandparent entrusted to puun-the customary leader of Baduy)

(Negara tiga puluh tiga/ The thirty three-states) (Sungai enam puluh lima/ The sixty five-rivers )

(Pusat dua puluh lima negara/ The center of twenty Five-states)

(Gunung tidak boleh dihancurkan/ Prohibition to destroy mountain)

(Lembah tidak boleh dirusak/ Prohibition to damage valey)

(Larangan tidak boleh dilanggar/ Never break the rule)

(Buyut tidak boleh diubah/Never change the ancestral prescriptions)

(Panjang tidak boleh dipotong/ Never cut the long)

(Pendek tidak boleh disambung/ Never connect the short)

(Memulai mesti izin, mengambil mesti meminta/ To start should permit, to take should ask)

(Berjalan mesti memberi tahu/ To walk should inform)

(Memotong mesti sepotongnya/ To cut should be a piece)

(Menebas mesti seadanya/ To slash should be sober) (Membacok mesti sekaligus/ To slice should at once) (Yang tidak katakan tidak/Say no to something not owned/)

(Yang benar harus dibenarkan/ The truth must be justified)

\section{Sunda Wiwitan and Sasaka Domas Symbols in the Baduy Indigenous Peoples}

Observing the appreciation and religious behavior of the Baduy indigenous people, it was found that two crucial forms of symbols were considered sacred by them, namely Sunda Wiwitan and Sasaka Domas. These two sacred symbolic forms are used as a way to represent something that is not reached by the senses within the limits of cultural reason, and beyond the boundaries of description that can be done by the Baduy indigenous people.

Sunda Wiwitan and Sasaka Domas are two sacred symbols that oriented to express, represent, and communicate knowledge. These two symbols also relate to the transcendental experiences that go beyond the immanent boundaries of the Baduy indigenous people, where they cannot reach and enter the transcendent region because of its limitations. So, to achieve that region, they use analogies and metaphors to transform their knowledge and immanent experience when dealing with the "Transcendent," so that they can feel the presence of the "Sacred" or "Eternal." 


\section{Sunda Wiwitan Symbol}

Based on the observations, this research found that Baduy indigenous people, especially those who lived in three villages tangtu (telu tangtu), namely tangtu Cikeusik, tangtu Cikertawana, and tangtu Cibeo, showed a level of appreciation to Sunda Wiwitan belief is so strong. The Baduy indigenous people communicate it among family and community members as well as customary leaders in the performing of various commands and teachings they believe. Their communication is constructed by their cultural pattern in daily life. The way of communication on religious belief is through daily behavior in the form of a "carek" (prohibition) that is reminiscent of not committing acts that are taboo (buyut) or prohibited by customary law. The pattern of communication in the Baduy indigenous people is influenced by the pikukuh karuhun, which teaches about "penance in the mandala."

The appreciation of religiosity of the Baduy indigenous people in their daily activities is showed that they understand all the risks or consequences of their acts when transgressing the traditional law that is framed by Sunda Wiwitan teachings. Thus, many people would be careful not to act that contrary or taboo (buyut) to the teachings they believe.

Understanding of their beliefs (Sunda Wiwitan) can be seen from their ability to explain the taboo or prohibited of Sunda Wiwitan teachings. Sometimes, this belief system is called Sunda Wiwitan Slam. Ayah Asrap (Personal Communication, May 17, 2012), former Jaro Pamarentah, who lives in the Kaduketug area, said: "Our religion is Sunda Wiwitan Slam." The persistence of the Baduy indigenous people in Sunda Wiwitan's beliefs can be seen from the statement: "Mun Sakabeh tatangkalan geus taya racuna, beunang didahar. Mun sakabeh sasatoan teu haram didahar. Mun sakabeh jelema sarua kasepna sarua geulisna, di dunya taya nu goreng, kakara di dinya agama teh ngan hiji. Aing dek asup kana agama eta (If all plants are no longer toxic, and can be eaten. If all animals are not forbidden and can be consumed; If all humans are equally beautiful, and no one is ugly. Only then is there only one religion. Thus, I will convert to that religion). The statement showed a strong appreciation of Sunda Wiwitan's beliefs.

Based on observations in the field, this research shows that Sunda Wiwitan religion has not many religious teachings and worship rituals to God they believe. As explained above, Baduy community belief in the highest authority called the Batara Tunggal (Almighty God) that resides in Buana Nyungcung.

Buana Nyungcung is one of the cosmic concepts in the cosmology of Kanekes society. Ayah Mursid (Personal Communication, May 17, 2012) explains that:

Alam nu aya di jagat raya sakabehna aya tilu: (1) Buana Nyungcung, tempatna Sanghyang Keresa, ayana paling luhur; (2) Buana Panca Tengah, tempat manusa jeung makhluk sejena nya eta alam dunya; (3) Buana Larang, nyaeta hiji tempat panghandapna, nu disebut naraka.

(There are three realms in the universe: (1) Buana Nyuncung, where Sanghyang Keresa (the Almighty) is, at the top; (2) Buana Panca Tengah, a place where humans and other creatures are the natural worlds; (3) Buana Larang, which is the lowest place, which is called hell).

In the faith of the Kanekes, the world (Central Continent) is divided into several levels of purity. The explanation of the region and the level of purity of this world is explained by Ayah Mursid (2012): "Ceuk Ajaran Kami, Buana Panca Tengah atawa alam dunya dibagi-bagi kana sababaraha bagian: (1) Sasaka Pusaka Buana anu disebut Sasaka Domas, eta tempat paling suci; (2) Kampung tangtu (Cikeusik, Cikertawana, jeung Cibeo), tingkat kasucianana handapeun Sasaka Pusaka Buana; tuluy (3)Panamping; (4) Banten di luar Baduy; (5) Taneuh Sunda nu aya di luar; (6) Luar Sunda." (According to our teaching, Buana Panca Tengah or the natural world is divided into several sections: (1) Sasaka Pusaka Buana, called Sasaka Domas, the holiest place; (2) Tangtu village consisting of Cikeusik, Cikertawana and Cibeo, the level of purity below Sasaka Pusaka Buana; then (3) Panamping; (4) Banten outside Baduy; (5) Sundanese land outside Banten; (6) the land Outside Sundanese region;

The Kanekes people treat Sasaka Domas as the most sanctified place to this day. Not everyone allowed to visit at any time. Only certain people can visit this sacred place. Among them are Puun, Jaro, kokolotan, and people who have permission from the Cikeusik Puun. Whereas in the Tangtu region, the level of sanctity is under the Sasaka Domas, and it also has several provisions applied. Not anyone can visit or stay in these three tangtu (villages). People who are allowed to settle or reside in the three 
regions of tangtu (telu tangtu) are only direct descendants of each tangtu part, and that is only allowed for those who do not violate the customary law that is applied to each of these areas.

According to Ayah Mursid (Personal Communication, May 17, 2012), several teachings of the Sunda Wiwitan Slam related taboo (buyut) consists of:

1) Buyut Adam Tunggal nu husus keur Urang tangtu. Nya eta sakabeh buyut nu aya di Baduy, nepi $k a$ buyut anu diwenangkeun dipigawe $k u$ urang panamping teu wenang dipigawe ku urang tangtu (Taboo that specifically directed to tangtu residence)

2) Buyut Nahun, buyut keur urang panamping jeung urang dangka. Hiji aturan buyut anu sifatna pokok (taboo that administered to panaping and dangka people).

In other words, buyut Adam tunggal is a taboo that covers a wide range of restrictions to a minimum of one degree only for those living in some tangtu regions (Cikeusik, Cikertawa, dan Cibeo). While buyut nahun is proscription (buyut) that applies to people outside tangtu villages, that is, to the panamping village and dangka.

According to Jaro Dainah (Personal Communication, May 5, 2012), Jaro Pamarentah, some of the humanitarian tasks that are required to be performed by Indigenous Baduy people according to the teachings of Slam Sunda Wiwitan are:

Kahiji, Ngaréksakeun Sasaka Pusaka Buana; Kadua, Ngaréksakeun Sasaka Domas; Katilu, Ngasuh ratu ngajayak ménak; Kaopat, Ngabaratapakeun nusa telu puluh telu, bagawan sawidak lima, pancer salawé nagara; Kalima, Kalanjakan kapundayan; Keenam, Ngukus ngawalu muja ngalaksa.

(That is; (1) maintaining shrines in Sasaka Pusaka Buana; (2) keeping shrines in Sasaka Domas; (3) nurturing the authorities and holding the state officials; (4) maintaining thirty-three homeland, sixty-five rivers, and twenty-five state centers; (5) hunting and fishing for the kawalu ceremony; and (6) burning incense when worshiping, carrying out the Kawalu ceremony and Ngalaksa ceremony).

\section{Symbols of Sasaka Domas}

The primary sacred symbol in the Sunda Wiwitan of Indigenous Baduy society is Sasaka Domas or Sasaka Pusaka Domas. The Baduy indigenous people also called it an "heirloom and is believed to be "the center of the earth" or "pancer bumi." This area is restricted to visit by anyone and at any time.

Sasaka Domas by certain tangtu people was cleaned once a year. According to the explanation from Ayah Juli (Personal Communication, May 22, 2012), a resident of Cibeo's hometown, said: "Sasaka Domas teh mangrupa tempat, lain kuburan, tapi ciri yen di dinya teh ayana Sasaka Telu puluh Telu, Bagawan Sawidak Lima, Pancer Salawe Nagara." (Sasaka Domas is a place, not a cemetery;it is a feature of "Sasaka Teulupuluh Teulu, Bagawan Sawidak Lima, Pancer Salawe Nagara."

Based on the findings, the residents of the Kanekes who live or occupy the telu tangtu (Cikeusik, Cikertawana, and Cibeo), let alone those living in the panamping village and dangka, know little about "what and where" of Sasaka Domas. However, almost all Baduy indigenous peoples believe in the existence of Sasaka Domas as an important and sacred symbol.

During the visit for the research, when asked the ordinary Baduy people about Sasaka Domas and where it located, many of them shook their heads. They even expressed 'teu wasa kami mah' (I have no power or ability to explain). The only informant who could explain Sasaka Domas and the place or area of Sasaka Domas whereabouts was the Ayah Mursid, a Deputy Jaro Tangtu Cibeo (Ayah Mursid, Personal Communication, May 17, 2012).

This research found that the Kanekes public did not know about Sasaka Domas because this sacred place is restricted to visit by ordinary people. Mainly the outsider like the researcher for this research did not receive permission to visit the Sasaka Domas area.

According to Ayah Mursid (Personal Communication, May 17, 2012), Deputy Jaro Tangtu Cibeo, said that Sasaka Domas is visited once a year on the fifth month according to the calendar of Baduy to clean, ngukus, and other specific purposes. The person who is allowed to visit Sasaka Domas area are: 
1. Para pamingpin adat, nyaeta: Puun, Girang Seurat, Jaro Tangtu, Wakil Jaro Tangtu, jeung Baresan. (The customary leaders are: Puun, Girang Seurat, Jaro Tangtu, Deputy JaroTangtu, and Baresan).

2. Jaro Pamarentah jeung para Pangiwana mun geus diizinkeun ku Puun Cikeusik. (Jaro Pamarentah and it's Pangiwana as authorized by the Puun Cikeusik).

3. Urang tangtu (Cikeusik, Cikertawana, Cibeo) nu boga tujuan khusus, kitu ge mun diizinan ku Puun Cikeusik. (Certain Tangtu peoples from Cikeusik, Cikertawana, Cibeo with special purpose, on the permission of the Puun Cikeusik).

4. Urang panamping (Baduy Luar, the outer Baduy) nu tinggal di wilayah Kanekes atawa tinggal di luar Kanekes tapi kudu aya izin ti Puun Cikeusik. (the Panamping people who live in the outer Baduy area, in Kanekes with permission from the Puun Cikeusik).

Another sacred form in the Sunda Wiwitan as part of the Sasaka Buana is the mandala. The word mandala comes from the Sanskrit word, which means "circle," or "center." Mandala is often defined as the center of the sacred and closed world in a cosmos order that eliminates chaotic demonic regions that are broken apart. The Mandala can be interpreted as the pure essence of the existence of 'the One' in the human world. Thus, the presence of 'the One' in human space is called 'Wastu-Purusha-Mandala,' or purusha mandala world. Meanwhile, the center of the mandala space is called 'Brahmastana' which Jakob Sumardjo refers to as the center of hiranyagarbha or Golden Womb (primordial point of cosmic seed light) (Sumarjo, 2003).

\section{The Ceremony of Baduy Indigenous Peoples}

The traditional ceremony is a symbol that represents three crucial issues, namely: (1) Symbolization of religious understanding and appreciation of the Baduy indigenous people as Sunda Wiwitan descendants; (2) Symbolization of the observance and practice of daily life of the Baduy indigenous people as members of the traditional Sundanese social group or Sunda Buhun; and (3) Symbolization of the existence and recognition of the existence of government and power outside the Baduy Customary institution.

Baduy indigenous people have three rituals, namely kawalu, ngalaksa and seba. These three important traditional ceremonies represent the transformation of "before" to "after" based on the ideals of primordial culture.

\section{Kawalu Ceremony}

The Kawalu traditional ceremony is held in the kasa, karo, katiga months, based on the dating of the Baduy (Kanekes) indigenous people. The three months are considered sacred months because it involves a special religious day, namely the month of Kawalu. In these Kawalu months, the Kanekes community conducted various traditional activities to purify themselves physically and mentally. One of them is fasting one day each month, by not eating the meal beforehand and breaking the fast is regulated following the provisions of customary law, which is around $6 \mathrm{pm}$.

The Kasa month is called Kawalu Tembey, meaning Early Kawalu. Tembey or mitembeyan is a Sundanese term means starting, while the karo month is called Middle Kawalu, while in the katiga month is called Kawalu Tutug or final Kawalu. In addition to fasting activities, the Baduy people perform the cleaning activities such as clean objects produced by modern technology that used by the Baduy community, as well as clean the impure act of transgressing or violating the taboo (buyut). It is carried out by the Baduy community as well as outside the Baduy community. It is carried out within the tanah ulayat Baduy (Baduy land).

These cleaning activities occur in two categories: First, physical or material cleansing for those who are considered violating the customary law. Second, spiritual cleansing related to clean the problems that occur as a result of transgressing the taboo committed by Baduy residents or outside Baduy residents in Baduy's ulayat land, which is considered to have polluted the ancestral property and polluted the soul or spirit. 
Other activities carried out in this kawalu month are expressing gratitude to Nyi Pohaci Sanghyang Asri or the goddess of rice for her generosity, which has blessed the harvest. Ayah Mursid (Personal Communication, May 17, 2012), Deputy Jaro Tangtu Cibeo, sated:

Kawalu nurutkeun keyakinan Baduy mangrupakeun bulan suci, bulan kebahagiaan dan kemuliaan nu eusina mangrupa kegiatan-kegiatan, mulai berdoa jang kasalamatan alam jeung manusia tur eusina, beribadah mohon ampunan dosa tina mangrupa-rupa kesalahan, utamana kesalahan mangrupa ngarusak lingkungan alam atawa ngotoran alam, bersyukur tina kasalametan, kesehatan jeung keberhasilan ngalaksanakeun rukun ibadah agama Sunda Wiwitan jeung amanat-amanat leluhur. Ari nu disebut Kawalu nyaeta bulan dibukana pamenta ka Yang Mahakuasa nu nyiptakeun bumi jeung langit, bulan nu pinuh barokah, bulan keur ngabersihkeun diri jeung ngadeukeutkeun diri ka anu Kawasa.

(According to Baduy's belief, Kawalu is a holy month, a month of happiness and glory. Several activities for this ritual are praying for the safety of nature and humans and their contents, worshiping, asking forgiveness of sins from all things that damage the nature or polluting nature, thankful for safety, health and success in carrying out the harmony of Sunda Wiwitan religion and the mandates of the ancestors. Kawalu is the month the request is opened to the Almighty, who created the earth and sky, a blessed month, a month to cleanse itself and get closer to the Almighty).

The density of traditional events in these three months is often referred to as the Bulan Larangan (Prohibition Months) in which the entire Baduy area is closed to visitors or guests. In an emergency, visiting is allowed with strict permission from the Kanekes village officials or jaro pamarentah.

\section{Ngalaksa Ceremony}

Based on the results of interviews with Jaro Alim (Jaro Tangtu Cikeusik), as well as elders of the Jaro tangtu region, and Deputy Jaro Tangtu Cibeo (Ayah Mursid), ngalaksa is an implementation of the Sunda Wiwitan religious pillars. This ceremony is focused on ritual to pray for the safety of humanity, ngajiwa batin, ngalaksanakeun amanat titipan leluhur who must be carried out by the Baduy community (Kanekes). The activity in this ceremony is reciting special prayers following the customs. The ngalaksa ceremony is held in the month of kasa and katiga.

In the kasa month, ngalaksa huma serang is carried out only in Baduy Dalam. In the katiga month it is carried out by all Baduy residents, starting from the Baduy Dalam, proceed to the panamping and dangka areas, starting from Cikeusik, Cikertawana and Cibeo, and then to the panamping area and dangka that located in the outer Baduy region. This ceremony is end at 27 Kawalu Tutug in Dangka Warega.

The Ngalaksa ceremony is conducted in private and is not permitted for people outside of Baduy (Kanekes) to participate. Jaro Alim, Jaro Tangtu Cikeusik (Personal Communication, May 17, 2012), states:

Hampura pisan ka Bapa jeung rombongan, lain kami teu ngahargaan jeung teu ngahormat kana pamenta, ku sabab eta acara Ngalaksa teh hiji pagawean tina rukun adat kami anu pokok, jeung ceuk aturan teu meunang ditingali ku urang luar, wayahna pisan isuk subuh bapak jeung rombongan kudu geus teu aya di wilayah tangtu Cikeusik. Ku naon kami nitah balik sabab eusina ngalaksa nu intina ngadoakuen jeung ngalaporkeun jumlah warga husus Baduy secara lahirna jeung sacara bathina ka luluhur tur ka nu Maha Kawasa. Acara ieu deukeut pisan jeung masalah ritual tatakrama anu teu perlu dipakanyaho ku umum, bisi aya kajadian anu teu dipiharep, atawa bencana.

(I apologizes to you and the group, it does not mean that we do not respect and welcome you, but ngalaksa event is one of the main pillars of traditional ceremony, and according to the customary rules, it should not be witnessed by outsiders. Please be advised that by tomorrow morning you should leave the Cikeusik. Why do we ask or order you to go because the contents of ngalaksa activity is to pray and report the number of Baduy residents to the ancestors and the Almighty. This event is not supposed to be witnessed and known by the public. I am afraid that it will cause unexpected disasters). 
The data that can be gathered regarding the implementation of Ngalaksa traditional ceremonies were received from Ayah Mursid (Personal Communication, May 17, 2012), the Deputy Jaro Cibeo, or Jaro Parawari, who served as the informant of the Baduy customary institution. He explained that:

"Hartina ngalaksa nurutkeun kayakinan agama kami Sunda Wiwitan kabagi kana dua: Kahiji, ngalaksa teh bagian tina ngalaksanakeun rukun agama Sunda wiwitan, sifatna ngadoakaeun kasalametan sakabeh umat manusa supaya ngajiwa batin. Kadua, ngalaksanakeun amanat titipan karuhun nu wajib dilaksanakeun ku sakabeh masyarakat Baduy nu dimimitian ku ngadoa husus nu geus diatur ku hukum adat. Pelaksanaan upacara adat ngalaksa dilaksanakeun di bulan Kasa jeung Katiga. Dina bulan Kasa ngalaksa huma serang nu khusus di tanah ulayat tangtu, dina bulan Katiga dilaksanakeun ku sakabeh warga Baduy, dimimitian ti Baduy Dalam, diteruskeun ka panamping jeung dangka, sakumaha nu geus di atur ku hukum adat, mulai ti Cikeusik, Cikertawana dan Cibeo, terus ka panamping jeung dangka nu aya di wilayah Baduy Luar, ditutup tanggal 27 Kawalu Tutug di Dangka Warega."

(The understanding of ngalaksa according to Sunda Wiwitan religious beliefs, is divided into two. First, Ngalaksa is part of the implementation of the sacred pillars of Sunda Wiwitan, its nature of praying for the safety of all humankind, the soul's mind. Second, carrying out the mandate entrusted by the ancestors that must be carried out by all the Baduy community that begins by reciting a special prayer that has been regulated by traditional law. The Ngalaksa ceremony is held in the Kasa and Katiga months. In the month of Kasa, Ngalaksa huma serang specifically carried out in Baduy Dalam (land ulayat tangtu); the month of Katiga is carried out by all Baduy residents, starting from the Baduy Dalam, proceed to the panamping areas and dangka as regulated by customary law, starting from Cikeusik, Cikartawana, and Cibeo, continued to the panamping area and the dangka in the outer Baduy area, end at 27 Kawalu Tutug in Dangka Warega).

Interview with Ayah Mursid (Personal Communication, May 17, 2012) found that Ngajiwa batin means to be born and inward. According to his explanation:

"Ngajiwa batin hartina manusa boga raga jeung jiwa atawa batin. Jadi tiap tahunna nurutkeun kayakinan kami kudu disetorkeun ka Puun keur didoakeun ka nu ngabogaannana supaya jiwa ragana jeung supaya hirup jeung huripna salamet. Jadi ngalaksa teh wajib dilaksanakeun $k u$ kabeh warga kampung nu aya di Baduy salila tujuh poe dimimitian ti tanggal 20 nepi ka tanggal 27 bulan Katiga" (Ngajiwa batin means human being consists of body and soul. So every year, according to our belief, it must be deposited to Puun to pray to the human owner so that his soul and body and all his life are safe. So, Ngalaksa must be carried out by all residents of Baduy for seven days, starting from the 20th to the 27th in the katiga month).

The order of the implementation of ngalaksa in Baduy is as follows:

1) Cikeusik and Cikertawana villages on the 21st (salikur) in Katiga month;

2) Cibeo Village on the 22nd (dua likur) in Katiga month;

3) Kadu Ketug Village on the 23rd (tilu likur) in the Katiga month;

4) Dangka Cibengkung 24th (opat likur) in the month of Katiga month;

5) Dangka Cihulu on the 25th (lima likur) in the Katiga month;

6) Dangka Garehong on the 26th (genep likur) in Katiga month; and

7) And finally in Dangka Warega on the 27th (tujuh likur) of Katiga month.

After finishing the ngalaksa event on 27th, the two to four days left in Katiga month do not count to include as the end of the year or the beginning of the year. Those days are considered as rounding up (diwagekan). Therefore, the number of days in a year, according to the Baduy custom calendar system is 360 days.

Based on the data collected, the purpose of seven days' performance of the ceremony means to allow the people who are not recorded in previous days. On the seventh day is the last day to fulfill it.

The understanding of Ngalaksa begins with making laksa made from rice flour harvested by all Baduy residents that year intended as offerings to the ancestors and for gifts given to government officials during the Seba event. Ngalaksa ceremony is also often referred to as seren tahun. 
Sajen ritual is a ritual that presents the work of humans to Sang Hyang Kersa (the Creator) as a form of appreciation and gratitude. This offering ritual is a medium to describe the relationship between humans and the Creator, the human with other humans, and humans with nature (Melina \& Azeharie, 2020).

Ayah Mursid (Personal Communication, May 17, 2012), Jaro Tangtu Cibeo's representative, stated that: "Seren bulan seren tahun, nyerenkeun tahun nu kaliwat, nyambut nyanghareupan tahun nu bakal datang." (This ceremony is to restore the month and year of the past, and to welcome the new year to come."

So, the ngalaksa event is a symbol of Baduy's custom to release the past year and welcome the new year to come with the aim that all Baduy residents (Dalam and Luar) get safety, peace and avoid disaster by invoking protection from the Creator and Lord of the universe. The Ngalaksa traditional ceremony in the Kanekes community is a symbol that represents Sunda Wiwitan religious appreciation.

Ngalaksa adat can be seen sociologically as an instrument in understanding the world and is part of the world view of the local community, which is influenced by their belief represented in religious teachings (Aliyudin, 2016). Thus, these belief systems will continue influencing and even shaping the social structure and culture of the Baduy indigenous community.

\section{Seba Ceremony}

Other symbolic forms of traditional ceremonies found in the Kanekes (Baduy) community is Seba traditional ceremony. Seba ritual is different from the Ngalaksa ceremony. Seba is an obligation or a customary pillar that must be carried out every year at the beginning of the Baduy conventional year, recommended by the pikukuh to nurture the Queen and the noble (ngasuh ratu ngajayak menak).

Jaro Dainah as Jaro Pamarentah of Kanekes village, explained that:

Seba teh adat nu diwariskeun ku karuhun ti baheula nepi ka ayeuna keur nyanghareup ka ratu jeung menak, tujuanana keur ngadeukeutkeun jeung ngalaporkeun situasi jeung kaayaan masyarakat Baduy, lingkungan alam Baduy, jeung harepan masyarakat Baduy ka pamarenta (Jaro Dainah, Personal Communication, May 18, 2012).

(Seba is a custom inherited from ancestors to respect the leaders and aristocrats, to maintain relationship and report the problems and circumstances of the Baduy community, the Baduy natural environment, and the expectations of the Baduy community to the government).

Jaro Dainah further mentioned that Seba could be interpreted as an attitude of respect and appreciation of the Baduy community towards the government by conveying the yields of residents in the hope that it can be enjoyed by the government officials. Seba is obligatory to be held once a year in the month of Safar beginning of the new year under the Baduy calendar. It performed a week after ngalaksa event around the 1st to 9th of Safar and should not exceed the 10th of the Safar month. Considering Seba is compulsory to be carried out, the elders of Kaduketug (Kokolotan Kaduketug) said, "Bisi engke dina hiji waktu atawa jaman Seba euweuh nu narima, poma tetep kudu dilaksanakeun sanajan ngan aya tunggul jeung dahan sapapan nu nyaksian." (If at some point in time no one wants to accept Seba ceremonial, please continue to do it even though there is only a piece of wood watching).

On another occasion, Ayah Mursid (Personal Communication, May 17, 2012), Deputy Jaro Tangtu Cibeo explained some of the urgency and the essence of Seba that contain eight issues to be understood in Seba, namely:

1) Seba is a religious activity that must be carried out by all Baduy residents, both Baduy Luar residents and Baduy Dalam residents.

2) Seba is a standard activity or traditional event that is routine or tradition that has been passed down since the tribe of Baduy was born.

3) Seba, in essence, is the Baduy gathering of the Empress and Menak (regional leaders) based on awareness and sincerity.

4) Seba has special rules so that the implementation is not arbitrary, through careful calculation, deliberation, and agreement of customary institutions with the government, so it is official.

5) Seba is not a tribute or a sign the Baduy submission to the government, because Baduy has never fought with anyone. 
6) Seba is a tribute and appreciation from the Baduy community to the government or gratitude for the happiness of the Baduy community to who has finished implementing the pillars of wiwitan, so that at the event brought and handed over a portion of Baduy harvest voluntarily.

7) Seba is an activity entrusted by the ancestors to deliver wiwitan mandates to the government in the form of mutual assigning, reminding, reporting, and praying physically and mentally so that humans, nations, and countries remain safe from disaster and damage.

8) Seba is a unique media to convey various problems to the government (Ratu and Menak), related to traditional complaints, events that happen to customs, and customary expectations. So every Seba event, the mission carried varies according to the situation and conditions at that time.

The Ayah Mursid (Personal Communication, May 17, 2012), vice Jaro Cibeo, in detail, explains about Seba:

Mun ceuk Sundana mah kieu Seba teh salah sahiji rangkaian kagiatan kaagamaan anu dipusti-pusti saenggeus ngalaksnakeun upacara Ngalaksa panutup tahun. Eta Seba dilaksanakeun satahun sakali satiap awal tahun saminggu geus ngalaksa, waktuna antara tanggal 1 nepi ka tanggal 9 bulan Sapar pananggalan Baduy. Eusina Seba di antarana nepikeun kawajiban mangrupa amanat-amanat sacara langsung ka Ratu jeung menak oge pamarentah husuna nu jadi kabeubeurat adat, keluhan adat, negeskeun jeung mere pepeling mana nu kudu ditegeskeun, mana nu kudu diperenahkeun jeung mana anu kudu dilaksanakeun ku menak atawa pamarentah supaya ieu alam jeung lingkungan tetep ayem tengtrem, sabab jalma mah ngan bisana ngaruksak alam, nyieun jeung ngabebenahna mah can puguh bisa. Lamun ieu acara Seba teu diperhatikeun maka pamarentah kudu siap nanggung risiko jeung akibatna mun aya mamala. Ku sabab datang langsung, piraku lengoh makana mawa hasil bumi atawa hasil tatanen keur nyukuran kana kabahagian, tapi ku urang luar sok disebut Seba teh mangrupakeun pestana urang Baduy.

( $S e b a$ is one of a series of religious activities that are genuinely exalted after carrying out ngalaksa traditional ceremonies. Seba is held once a year at the beginning of the year, one week after ngalaksa, and it is the ceremony conducted for the year. The time is from the 1st to the 9th month of Safar under the Baduy calendar. During the Seba ritual, people convey their obligations and direct mandates to the Queen and the aristocrats as well as the government. On this occasion, people administered burdened with adat responsibilities, adat complaints, then affirmed and gave advice which should be confirmed, resolved, and carried out by leaders or governments so that nature and the environment remain safe. The reason is that humans are usually destructive and unable to preserve it. If the Seba event is not heeded, the government must bear the risks and consequences of disasters. Because it comes directly, the residents bring crops to be submitted to the government as an expression of happiness and gratitude. Many outsiders called Seba the party of the Baduy peoples).

Based on interviews, Seba is a special medium to express gratitude to the government by giving some parts of the agricultural products of the Baduy community. It is also symbolically representing the Baduy people's respect towards the government, and recognition that the Baduy indigenous people (Kanekes) are part of the Indonesian Republic. Seba traditional ceremonies are joint events conducted by leaders, actors, and participants of the ceremony. The participants of the ritual are not allowed to leave the event before the ceremony is over.

\section{Meaning of Baduy Indigenous Peoples Regarding Sunda Wiwitan Symbols}

In the context of this study, the symbols in the Baduy indigenous people are not something separate from their socio-cultural representation. It conceptualizes to represent the objective reality that they want to convey. The forms of symbols used to describe something to be expressed by a person or social group, according to Suzanne K. Langer can be divided into two categories, namely discursive symbolism and presentational symbolism (Sumarjo, 2003).

Discursive symbols are symbols that are not related and are used in written and oral language for communication with other parties. This symbol is a description of something. Whereas, the 
presentation symbol (presentational or non-discursive) is a presentation of meaning that is unspeakable in a discursive symbol, therefore this symbol indescriptive.

Based on observations of the forms of symbols used by the Baduy indigenous people, it is known that the symbols are used as a form of conceptualization of ideas, or values, and are used to represent the objective reality that they wish to convey. In general, the symbols used in the form of the symbolic that is depicted, because the factual reality of most of the symbols used by the Baduy indigenous people are not in written form. The Baduy people is not a written culture, and also not much in an oral way even though they can be classified as speech communities. They are more likely to use the form of concrete symbols, which are symbols that represent objects, also though some issues seem ambiguous because it is an abstract symbol that represents a thought or idea without any concrete explanation.

Besides the forms of symbols used to represent the meaning conveyed refers not only to concepts or ideas, but also to the transcendent, the absolute, such as concepts, definitions, values, beliefs, and transcendent existence. In this case, the forms of symbols used are not only referring to the ideas (ratios) and experiences of the Baduy indigenous people, but symbolic forms to present supernatural powers or energy the "Absolute. It is supernatural that is not experienced in the time and space dimensions of the Baduy indigenous people.

Thus, among the symbolic forms used by the Baduy indigenous people represent "the Sacred" to transcend all abilities of the description as well as the limitations of local-primordial reasoning of the Kanekes people. This representation is in line with Suzanne K. Langer, who stated that: "Only by using symbols, humans can achieve high potential and life goals" (Dillistone, 2002).

Based on the perspective of symbolic interactionism, the ability of humans to find or achieve life goals that are higher or more meaningful by using symbols is a uniquely human ability called the mind. The ability to find meaning and show it to others is an ability that gives humans unique strengths. The control mechanism of meaning in this sense is called the mind, namely the ability to use symbols that have social implications, as explained by George Herbert Mead, that mind is the human ability to use symbols that have the same social meaning.

In Baduy indigenous people, the ability to find or achieve a higher or more meaningful life is manifested in their collective belief of Sunda Wiwitan Religious symbol, and the sacred symbolic form, Sasaka Pusaka Buana. Mircea Eliade calls "an important religious symbol is not only used to represent the world and "the sacred," but also is a continuity between the structure of human existence and the cosmic structure (Pals, 2011).

Religious symbols in the form of the collective belief of the sacred found in the Baduy indigenous people, following Mircea Eliade as "Symbols that express sacred or cosmological realities that cannot be stated by other manifestations" (Dillistone, 2002). A symbol functioned to erase human boundaries in society and the cosmic so that humans are not just "fragments," but make their deepest identity and social status more clearly. Symbols also make themselves one with the rhythm of nature and integrate it into a higher unity, the unity of society, and the universe.

The form of religious symbols in the form of collective belief and the sacred forms above, by the Kanekes people, is used to find and achieve a higher or more meaningful life by carrying out the pillars of religion, consisting of: "Ngaréksakeun Sasaka Pusaka Buana, Ngaréksakeun Sasaka Domas, Ngasuh ratu ngajayak ménak, Ngabaratapakeun nusa telu puluh telu, bagawan sawidak lima, pancer salawé nagara, Kalanjakan kapundayan, Ngukus ngawalu muja ngalaksa." (Maintaining a place of worship in Sasaka Pusaka Buana, Maintaining a place of worship in Sasaka Domas, Caring for the authorities and holding state officials, Establishing 33 homeland, 65 rivers, 25 national centers, hunting, and fishing for the Kawalu ceremony, Burning incense while worshiping, carrying out rituals Kawalu, and the celebration of making laksa). The pillars of religion were then seen as part of the duties of the Kanekes people.

According to Durkheim's analysis, all these ceremonies are symbolic expressions to strengthen and renew their commitment to the community, as Durkheim stated that, "religious beliefs and rituals are symbolic expressions of social reality" (Pals, 2011).

In the perspective of Durkheim and Mauss: "The religious nature of primitive symbolic societies, the social function of the symbolic meaning of ritual is the contribution made in shaping and 
maintaining social order" (Morris, 2006). The existence of religion inevitably varies according to the way society was formed. Therefore, religious institutions, through rituals, symbolize, and help maintain the existing social relations system.

The construction of symbolic forms in the Baduy indigenous people is built based on spirituality, nature, and culture contained in the local environment. This form of thought is based on the understanding and appreciation of Sunda Wiwitan. Based on that thought, references were produced as a result of the symbolic reference and conceptualization.

Various forms of symbols found in the Baduy indigenous people are a way of describing and representing the reality they want to convey based on the results of the construction of the existence of their daily lives. The various forms of symbols found in the Baduy indigenous also formed the socialcultural structure of the Baduy indigenous people.

Symbols in the form of Sunda Wiwitan used by the Baduy indigenous people are used to convey objective reality based on the appreciation and practice of their lives towards fellow citizens and communities outside the Baduy indigenous people. The sacred symbol institutionalized in the form of belief, namely Sunda Wiwitan religion, is the main symbol of the Baduy indigenous people, and is a dimension that extends broadly to every side of life, and is a collective representation of the Baduy indigenous people.

The symbol of "the sacred," which is a reference to the collective belief system, is used by the Baduy indigenous people as a reference to interpret natural phenomena and interpret and determine the actions of the Kanekes community. Sasaka Domas, as part of the "sacred," can be called a part of collective belief.

The symbols in Baduy traditional ceremonies represent three important issues, namely: (1) Symbolization of religious understanding and appreciation or belief of the Baduy indigenous people as Sunda Wiwitan descendants; (2) Symbolization of the observance and practice of the daily life of the Baduy indigenous people as members of a traditional Sundanese social group or Sunda Buhun; and (3) Symbolization of the existence and recognition of the existence of government and power outside the Baduy customary institution. Overall, the symbol forms used by the Baduy indigenous people categorize as presentational symbolism, since they use more tangible symbol than written or oral symbols.

The forms of symbols used by the Baduy indigenous people refer to the existence of a transcendent being. All these symbolic forms are the creative abilities of the Baduy people to find or achieve life goals that are more meaningful following local beliefs and cultures, to form a shared awareness. These symbols also represent the patterns of meaning over space and direction, and quasi-mystical, and have shaped attitudes and mental or psychological states of Baduy indigenous people who are then projected into individual lives amid their society.

Thus, the symbolic patterns and forms in the Baduy indigenous people are built based on spirituality, nature, and culture contained in the local environment, namely thinking based on the understanding and appreciation of Sunda Wiwitan.

\section{Conclusions}

This research concluded that the Sunda Wiwitan religion has become the main symbol in the Baduy indigenous people, and is a dimension that reaches broadly every side of life, and is a collective representation of the beliefs of the Baduy indigenous people. This symbol is a reference to the collective paradigm and as a reference for interpreting natural phenomena and determining the behavior of the Baduy indigenous people. The symbol of traditional institutions and traditional ceremonies are symbols that represent three essential issues, namely: (1) Understanding and appreciation of religion (belief) of Baduy indigenous people as Sunda Wiwitan descendants; (2) Observance and practice of the daily life of the Baduy indigenous people as members of the traditional Sundanese or Sunda Buhun social groups; and (3) Symbolization of the existence and recognition of the existence of government and power outside the Baduy customary institution. 


\section{References}

Aliyudin, M. (2016). Dakwah Kultural dalam Upacara Adat Ngalaksa. Ilmu Dakwah: Academic Journal for Homiletic Studies, 10(2), 271-289. https://doi.org/10.15575/idajhs.v10i2.1079

Clifford, G. (1973). The interpretation of cultures. New York: Basic Books.

Danesi, M. (2010). Pesan, Tanda, dan Makna: Buku Teks Dasar Mengenai Semiotika dan Teori Komunikasi. Yogyakarta: Jalasutra.

Dillistone, F. W. (2002). Daya kekuatan Simbol (The Power of Symbols). Yogyakarta: Kanisius.

Ekadjati, E. S. (2014). Kebudayaan Sunda, Suatu Pendekatan Sejarah. Bandung: PT Dunia Pustaka Jaya.

Hakiki, K. M. (2015). Keislaman Suku Baduy Banten : antara Islam dan Slam Sunda Wiwitan. Refleksi, 14(1), $25-54$.

Hakim, N. (2006). Cultural and Spiritual Values of Forests In Baduy Region, Banten, Indonesia. Wageningen University.

Holil, M. (2020). Myths of Nyi Pohaci Sanghyang Sri on Sundanese Ethnic: Efforts to Reconstruct the Values of Environmental Conservation. IOP Conference Series: Earth and Environmental Science, 469, 12054. https://doi.org/10.1088/1755-1315/469/1/012054

Isfiaty, T., \& Santosa, I. (2020). The Study of Lisung-Halu as the Personification of Women in Mythical World In World View of Agrarian Sundanese. Mudra Jurnal Seni Budaya, 35(1), 48-55. https://doi.org/10.31091/mudra.v35i1.997

Isnendes, R. (2016). Upacara Seba Baduy: Sebuah Perjalanan Politik Masyarakat Adat Sunda Wiwitan. Jurnal Masyarakat Dan Budaya, 18(2), 47-58.

Littlejohn, S. W., \& Foss, K. A. (2012). Theories of human communication. https://doi.org/10.1017/CBO9781107415324.004

Melina, M., \& Azeharie, S. S. (2020). Ritual Sajen pada Penganut Sunda Wiwitan (Studi Komunikasi Budaya pada Penganut Sunda Wiwitan). Koneksi, 3(2), 427-434. https://doi.org/10.24912/kn.v3i2.6431

Miharja, D. (2015). Sistem kepercayaan awal Masyarakat Sunda. Al-Adyan: Jurnal Studi Lintas Agama, 10(1), 19-36.

Moleong, L. . (2011). Metodologi Penelitian Kualitatif. Bandung: PT Remaja Rosdakarya.

Morris, B. (2006). Religion and anthropology: A critical introduction. https://doi.org/10.1017/CBO9780511814419

Mulyana, D. (2010). Metodologi penelitian kualitatif: paradigma baru ilmu komunikasi dan ilmu sosial lainnya. Bandung: PT Remaja Rosdakarya.

Nadroh, S. (2018). Pikukuh Karuhun Baduy Dinamika Kearifan Lokal di Tengah Modernitas Zaman. Jurnal PASUPATI, 5(2), 196. https://doi.org/10.37428/pspt.v5i2.117

Pals, D. L. (2011). Seven Theories of Religion: Tujuh Teori Agama Paling Komprehensif. In I. R. Muzir \& M. Syukri (Trans.), Inyiak Ridwan Muzir \& M. Syukri. edisi baru. Yogyakarta: IRCiSoD. Yogyakarta: IRCiSoD.

Qodim, H. (2019). Kampung Kuta Religion: Social, Economic and Religious Structures of Indigenous Community in West Java. Wawasan: Jurnal Ilmiah Agama Dan Sosial Budaya, 4(2), $144-160$. https://doi.org/10.15575/jw.v4i2.7746

Rosidi, A. (1984). Manusia Sunda: sebuah esai tentang tokoh-tokoh sastra dan sejarah. Jakarta: Inti Idayu Press.

Saringendyanti, E., Herlina, N., \& Zakaria, M. M. (2018). Tri Tangtu on Sunda Wiwitan Doctrine in the XIV-XVII Century. Tawarikh, 10(1), 1-14.

Saringendyanti, E., \& Mahzuni, D. (2018). Lord in Sunda Wiwitan Perception. International Journal of Medical Science, 5(7), 22-29. https://doi.org/10.14445/23939117/IJMS-V5I7P104

Sobur, A. (2017). Semiotika komunikasi. Bandung: Remaja Rosdakarya.

Spradley, J. P. (2007). Metode Etnografi. Yogyakarta: Tiara Wacana.

Sumardjo, J. (2009). Kosmologi dan Pola Tiga Sunda. Jurnal Imaji, 4(2), 101-110.

Sumarjo, Y. (2003). Simbol-simbol artefak budaya Sunda: tafsir-tafsir pantun Sunda. Jakarta: Kelir.

Syam, N. W. (2009). Sosiologi komunikasi. Bandung: Humaniora.

Syukur, A., \& Qodim, H. (2016). Islam, Tradisi lokal, dan konservasi alam: studi kasus di kampung dukuh kabupaten Garut. KALAM, 10(1), 141-168.

Wahid, M. (2012). Sunda Wiwitan Baduy: Agama Penjaga Alam Lindung di Desa Kanekes Banten. El-Harakah. https://doi.org/10.18860/el.v0i0.1888

Wessing, R. (1975). Cosmology and social behavior in a West Javanese settlement. University of Illinois at UrbanaChampaign.

(C) 2020 by the authors. Submitted for possible open access publication under the terms and conditions of the Creative Commons Attribution (CC BY SA) license (https://creativecommons.org/licenses/by-sa/3.0/). 